\title{
The Effect of Propolis and Non-Propolis Toothpastes on Salivary pH of Children of National Primary School (SDN) 62 Banda Aceh
}

\author{
Ainun Mardiah, Reca, Ika Kana Trisnawati \\ Department of Dental Nursing, Health Polytechnic of Aceh Ministry of Health \\ \{ainun_mardiah_66@yahoo.com\}
}

\begin{abstract}
Caries can be prevented by maintaining the cleanliness of the oral cavity. There are many ways to maintain oral hygiene, one of which is to brush the teeth with toothpaste. Many ingredients can stimulate salivary secretion, including propolis, a natural antibiotic with no side effects. Propolis can also reduce plaque on the teeth, which helps increase salivary $\mathrm{pH}$. This study aimed to investigate the effect of using propolis and no propolis toothpaste on children's salivary $\mathrm{pH}$. The study used the quasi-experimental method. The subjects in this study were all grade 5 students of National Primary School (SDN) 62 Banda Aceh totaling 60 children, taken using purposive sampling technique. The subjects were then divided into two groups, with 30 students each: group I brushing teeth using propolis toothpaste and group II brushing teeth using nonpropolis toothpaste. The data were analyzed by employing a paired sample t-test. The results showed that there was a difference in the salivary acidity $(\mathrm{pH})$ before and after brushing teeth using nonpropolis toothpaste with a mean difference of $1.02(\mathrm{p}=.000)$, whereas the acidity $(\mathrm{pH})$ of saliva before and after brushing teeth with propolis toothpaste had a mean difference of $2.22(\mathrm{p}=.000)$. It can be concluded that the use of toothpaste containing propolis was more effective for increasing the acidity $(\mathrm{pH})$ level of saliva. It is recommended that there be socialization in the use of toothpaste containing propolis as an effort to prevent dental and oral diseases (e.g. dental caries, gingivitis, and periodontitis).
\end{abstract}

Keywords: Cryptography, RSA, ElGamal, Public Key, Asymmetric

\section{Introduction}

the Caries is a disease resulted from a demineralization process on the hard tissues of the teeth (enamel, dentine, cementum) due to bacterial activity in the oral cavity. Caries is one of the most common dental and oral health problems in the community. There are a number of causes of caries, one of which is bacteria. Bacteria breaks down the carbohydrate substrate attached to the oral cavity and then forms plaques. This bacterial activity will continue along with the rise of the acidity level $(\mathrm{pH})$ of the oral cavity. This condition will eventually lead to decalcification of enamel, and white spot lesions will emerge that indicate the start of the caries process [1].

The 2013 Basic Health Research reported that $25.9 \%$ of the Indonesian population had tooth and mouth problems. It was also stated that $62.9 \%$ of the population in Aceh province experienced caries, and generally as much as $90.7 \%$ of the people brushed their teeth every day during the morning bath and afternoon bath while the proportion of people who brushed their 
teeth every day after breakfast was only $12.6 \%$ and before sleep $20.7 \%$ [2]. In addition, the report of the Banda Aceh City Health Office in 2014 showed that dental and oral diseases ranked 14 th out of the 20 biggest diseases with 4779 visits. According to the results of dental and mouth examinations in the 6-14 year age group in Banda Aceh in the UKGS activity, 34\% of children suffered from caries [3]. The state of oral and dental health in the Banda Aceh City area has suggested that dental and oral health status is still a concern.

Saliva is a complex fluid produced by several salivary glands such as the parotid, submandibular, sublingual, labial, buccal, and palatal glands. Saliva has several functions, including protecting tissues in the oral cavity by mechanical cleaning to reduce plaque accumulation on the tooth surface, lubricating the teeth elements, providing buffer, preventing bacterial aggregation inhibiting the colonization of microorganisms, providing antibacterial activity, helping the tasting and digestive functions, and helping repair the tissues [4]. The function of salivary protection is strongly influenced by changes related to composition and viscosity, acidity, ionization, and salivary proteins [5].

The normal level of acidity $(\mathrm{pH})$ ranges from 6.7 to 7.3. The degree of acidity and buffer capacity of saliva can be influenced by the rhythm of day and night (circadian cycle), diet, and stimulation of the speed of secretion. The effect of the circadian cycle shows that the acid level and saliva buffer capacity will be high when you wake up early in the morning, but then it will immediately decline. Also, 15 minutes after eating, the acid level and saliva buffer capacity will also increase due to mechanical stimulation, but after 30-60 minutes they become low. At night, the acidity and buffer capacity of the saliva will rise, but by midnight they will go down. During sleep, the salivary volume will decrease, the ratio of bicarbonate and hydrogen ions will also decrease to $\mathrm{pH} 4$, and the bicarbonate concentration is low.4 The speed of salivary secretion can directly affect $\mathrm{pH}$ in the mouth; if the speed of salivary secretion increases, the salivary $\mathrm{pH}$ will also increase, and likewise, the speed of salivary secretion reduces, the $\mathrm{pH}$ of saliva also gets reduced. Such situations have an impact on the process of demineralization and remineralization of the teeth since repeated $\mathrm{pH}$ reduction will lead to a demineralization process and the onset of caries [6].

Childhood is the beginning of behavior development; therefore, during this period, children are usually most vulnerable to any internal and external influences. Not surprisingly, children are also quite vulnerable to changes in health status, including caries. Children aged between 10-12 years, according to the WHO, are generally more cooperative, and thus, any dental and oral health studies should target this age group [7].

Maintaining the cleanliness of the oral cavity will prevent the caries process. To maintain oral hygiene, one way is to brush the teeth with toothpaste. Many types of toothpaste on the market have different contents and functions [8].

Many ingredients can stimulate salivary secretion, one which is propolis. Propolis is one of the natural products produced by bees which can be useful as an anti-bacterial, antifungal, and antiviral agent. Various types of products from bees that are beneficial to health are mentioned in the Qur'an Surah Al-Nahl verses 68-69, which explains that Allah SWT (God) specifically introduced the benefits of bees and their products to humans to be used as a natural cure for various diseases. Propolis is also an antibiotic because it contains ferulic acid and bioflavonoids. In addition, propolis is also known as a natural antibiotic without side effects. Flavonoids in propolis have been shown to have antibacterial activity against Streptococcus mutans, one of the dominant bacteria in the mouth and the main bacteria that causes caries. Propolis can also inhibit the growth of plaque on the teeth so that the salivary $\mathrm{pH}$ can increase [9].

Findings of the study on Bacillus de Koch and other similar research showed that propolis has a bactericidal effect on bacteria that trigger the formation of dental caries [9]. Propolis also 
has anti-inflammatory and antioxidant effects. The anti-inflammatory and antioxidant effects can be utilized by applying propolis to toothpaste. Regular use of toothpaste every time one brushes his/her teeth can help the effectiveness of propolis. The anti-inflammatory effect can be used to reduce and treat oral thrush and other periodontal diseases while the antioxidant effects are used as protection on the teeth and surrounding tissues against irritants [10]. Propolis is widely studied as a remedy that can cure diseases and is more largely used in the form of liquid, gel, or capsules. Propolis is currently used for general body health rather than for oral health. Research on the use of propolis in oral health is still being performed as well as the packaging process of propolis as an ingredient or drug to oral cavity health, such as toothpaste [11]. The most expected propolis efficacy in toothpaste is that it can significantly inhibit the growth of plaque-forming bacteria (antibacterial effect) although propolis also has other properties or effects, such as anti-inflammatory for oral thrush and other periodontal diseases [12].

Departing from the above discussions, it is interesting to study further the effect of using propolis and nonpropolis toothpaste on salivary $\mathrm{pH}$ among elementary students in Banda Aceh. A large number of toothpaste circulating today makes it relevant for the study to investigate the effect of toothpaste containing propolis. The importance of the study is that people can find out which toothpaste has the best impact on the $\mathrm{pH}$ of saliva.

\section{Methods}

This study was conducted in August 2017, employing the quasi-experimental research method with a pre-test and post-test only group design. The subjects of the study included all grade 5 students of class VA and class VB of SDN (public elementary school) 62 in Banda Aceh City, Aceh Province, with a total of 60 children. The subjects were then divided into two groups, with 30 children each: group I (class VA) brushing teeth using a toothpaste containing propolis, and group II (class VB) brushing teeth using nonpropolis toothpaste. The subjects were selected by using the purposive sampling technique.

The measuring instruments included $\mathrm{pH}$ strips, a diagnostic tool, and a status card. The data were analyzed by employing the paired sample t-test in the SPSS (level of significance $=p<.05$ ) to determine the differences in changes in the acidity level (salivary $\mathrm{pH}$ ) in the children before and after brushing teeth using propolis and nonpropolis toothpaste).

\section{Result}

\subsection{Univariate Analysis}

The univariate analysis in this study included the salivary $\mathrm{pH}$ in the treatment group I and the debris index in treatment group II, both before intervention (pre-test) and after the intervention (post-test). The results of univariate analysis are presented in the following descriptions:

\subsubsection{Level of Acidity (pH) of Saliva at Treatment I (Propolis Toothpaste)}

Table 1 shows that before treatment (pre-test) all subjects had acidic saliva, and after treatment (post-test), nearly all of them had normal $\mathrm{pH}$ of saliva. 
Table 1. Results of salivary $\mathrm{pH}$ of treatment I

\begin{tabular}{ccccc}
\hline \multirow{2}{*}{$\mathrm{pH}$ of saliva } & \multicolumn{2}{c}{ Before } & \multicolumn{2}{c}{ After } \\
\cline { 2 - 5 } & $\mathrm{n}$ & $\%$ & $\mathrm{n}$ & $\%$ \\
\hline Normal & 0 & 0 & 28 & 93.3 \\
\hline Acid & 30 & 100 & 2 & 6.7 \\
\hline Base & 0 & 0 & 0 & 0 \\
\hline
\end{tabular}

\subsubsection{Level of Acidity (pH) of Saliva at Treatment II (Non-Propolis Toothpaste)}

Table 2. Results of salivary $\mathrm{pH}$ of treatment II

\begin{tabular}{ccccc}
\hline \multirow{2}{*}{$\mathrm{pH}$ of saliva } & \multicolumn{2}{c}{ Before } & \multicolumn{2}{c}{ After } \\
\cline { 2 - 5 } & $\mathrm{n}$ & $\%$ & $\mathrm{n}$ & $\%$ \\
\hline Normal & 0 & 0 & 15 & 50 \\
\hline Acid & 30 & 100 & 15 & 50 \\
\hline Base & 0 & 0 & 0 & 0 \\
\hline
\end{tabular}

Table 2 depicts that before treatment (pre-test) all of the subjects had acidic saliva, and after treatment (post-test), however, half of them still had acidic saliva and another half had normal salivary $\mathrm{pH}$.

\subsection{Bivariate Analysis}

The bivariate analysis aims to test the hypothesis of the study. The hypothesis is tested by calculating the mean difference in two groups with the paired sample t-test. The statistics of treatment group I and treatment group II is provided as follows:

Table 3. Statistics of salivary $\mathrm{pH}$ in treatment I and II

\begin{tabular}{ccccccc}
\hline & \multicolumn{3}{c}{ Before } & \multicolumn{3}{c}{ After } \\
\cline { 2 - 7 } & $\begin{array}{c}\text { Mean } \\
\text { Diff } \pm \text { SD }\end{array}$ & $\mathrm{t}$ & $\mathrm{p}$ & $\begin{array}{c}\text { Mean } \\
\text { Diff } \pm \text { SD }\end{array}$ & $\mathrm{t}$ & $\mathrm{p}$ \\
\hline $\mathrm{pH}$ of Saliva & $2.22 \pm 2.11$ & -5.77 & $.000^{*}$ & $1.02 \pm 1.06$ & -5.28 & $.000^{*}$ \\
\hline
\end{tabular}

Description: * = significant

The above table indicates that in the treatment group I, there was an increase in salivary $\mathrm{pH}$ before and after brushing teeth with propolis toothpaste with the average difference of 2.22. On the other hand, in the treatment group II, there was a decrease in salivary $\mathrm{pH}$ before and after brushing teeth using nonpropolis toothpaste with the average difference of 1.02 . In both treatment groups, however, there was an increase in salivary $\mathrm{pH}$ which was statistically significant $(\mathrm{p}<.05)$.

\section{Conclusion}

the Propolis not only suppresses the growth of plaque bacteria, but also supports the successful treatment of periodontal diseases since propolis can help increase the body's immune system and heal damaged tissues or wounds, such as gum bleeding, postoperative wounds, or post-periodontal treatment [13]. 
In this study, toothpaste containing propolis was shown to be more able to increase the salivary $\mathrm{pH}$ compared to non-propolis toothpaste due to the addition of propolis active substances. Propolis is a natural product from bees; thus, toothpaste with propolis is of unlimited use not only for adults but also for children as it can help establish a life-conscious dental and oral lifestyle from an early age. Dental and oral health-conscious behavior should be introduced in childhood years so that it can become a life habit that will be carried out afterward. The findings in this study confirmed the benefits of having propolis in the toothpaste as propolis actively protects human teeth from bacteria, viruses, and fungi. The working speed and activity of propolis in inhibiting germ attacks are the hallmarks of propolis compared to other similar natural ingredients [12]. Propolis is a non-toxic natural product with many pharmacological properties. Some of the propolis contents identified are aglycones, cyanuric acid derivatives, and terpenoids. Flavonoids, the main contents of propolis, are known to have activity against oral microorganisms. Other biological activities in propolis include anti-inflammatory, anesthetic, and a protective cell for the mouth. Propolis contains antibacterial ingredients that can inhibit the growth of plaque-forming bacteria. Antibacterial components of propolis are polyisoprenylated benzophenone, galangin, pinobanksin, and pinocembrin [9].

\section{REFERENCES}

[1] I. S. Suwelo, Karies gigi pada anak dengan pelbagai etiologi (Kajian pada anak usia prasekolah). Jakarta: EGC, 1992.

[2] Badan Penelitian dan Pengembangan Kesehatan, Riset Kesehatan Dasar. Jakarta: Badan Penelitian dan Pengembangan Kesehatan Kementrian Kesehatan RI, 2013.

[3] Dinas Kesehatan Kota Banda Aceh, Profil kesehatan kota Banda Aceh 2013. Banda Aceh: Dinas Kesehatan Kota Banda Aceh, 2014.

[4] J. Handajani, R. M. Puspita, and R. Amelia, "Pemakaian kontrasepsi pil dan suntik menaikkan pH dan volume saliva," Dentika Dent. J., vol. 15, no. 1, pp. 1-5, 2010.

[5] P. D. V. de Almeida, A. M. T. Grégio, M. A. . Machado, A. A. . de Lima, and L. . Azevedo, "Saliva composition and functions: A comprehensive review," $J$. Comtemporary Dent. Pract., vol. 9, no. 3, pp. 1-11, 2008.

[6] T. A. Hidayani and J. Handajani, "Efek merokok terhadap status $\mathrm{pH}$ dan volume saliva pada laki-laki usia dewasa dan usia lanjut," Dentika Dent. J., vol. 15, no. 2, pp. 146$148,2010$.

[7] N. Tinanoff and J. M. Douglass, "Clinical decision-making for caries management in primary teeth," J. Dent. Educ., vol. 65, no. 10, pp. 1133-1142, 2001.

[8] Budiharto, Pengantar ilmu perilaku kesehatan dan pendidikan kesehatan gigi. Palembang: EGC, 2009.

[9] Franz, Sehat dengan terapi lebah (Apitherapy). Jakarta: PT. Elex Media Komputindo, 2008.

[10] A. Suranto, Terapi madu. Jakarta: Penebar Plus, 2007.

[11] I. Maldupa, A. Brinkmane, I. Rendeniece, and A. Mihailova, "Evidence based toothpaste classification, according to certain characteristics of their chemical compotition," Stomatologija, vol. 14, no. 1, pp. 12-22, 2012.

[12] Fortune Star Indonesia, "Propolis toothpaste the perfect touch for your teeth," Fortune Star Indonesia, 2009.

[13] Ivanhoe, "What's new in health care honey for your teeth," www.reallyrawoney.com, 2001. 